\title{
The Cyclical Behaviour of Real Wages: Evidence from Australia
}

\author{
George B. Tawadros \\ School of Economics, Finance, and Marketing, RMIT University, Melbourne 3001, Australia \\ Correspondence should be addressed to George B. Tawadros, george.tawadros@rmit.edu.au
}

Received 4 March 2010; Accepted 8 June 2010

Academic Editor: Jos van Ommeren

Copyright () 2010 George B. Tawadros. This is an open access article distributed under the Creative Commons Attribution License, which permits unrestricted use, distribution, and reproduction in any medium, provided the original work is properly cited.

This paper analyses the behaviour of real wages over the business cycle for Australia, using quarterly observations for the period $1984: 1-2008: 2$. The unobserved cyclical components of prices, real wages, and three other cyclical variables are extracted from the observed time series using Harvey's $(1985,1989)$ structural time series model. A model relating these components is estimated, producing results which show that both prices and real wages are procyclical.

\section{Introduction}

The cyclical behaviour of real wages has long attracted the interests of theorists and practitioners alike. Proponents of the Keynesian school of thought are in agreement with the classical economists that real wages are countercyclical, rising with cyclical contractions and falling with cyclical expansions, while real business cycle theorists believe that real wages have been procyclical during the post-World War II period. The existing empirical evidence is rather mixed, as support has been found for both contentions, while some studies have produced ambiguous results. This has lead Lucas [1, page 17] to suggest that "real wages are not constant over the cycle, but neither do they exhibit constant pro- or countercyclical tendencies." Similarly, Abraham and Haltiwanger [2, page 1262] conclude that "correcting for all of the measurement problems, estimation problems, and composition problems does not lead to a finding of systematically procyclical and countercyclical real wages." This finding by Abraham and Haltiwanger [2] is reaffirmed by Brandolini [3, pages 153-154], who suggests that "it is doubtful that a stylised fact exists" and that there is "no undisputed empirical regularity [that] has emerged so far".

The earliest empirical work analysing the cyclical behaviour of real wages is attributed to Dunlop [4] and Tarshis [5], who find a positive correlation between real and money wages. Given the procyclical movement of money wages, this finding was interpreted as evidence against the Keynesian proposition of a countercyclical real wage. The findings of Dunlop [4] and Tarshis [5] were challenged by, inter alia, Keynes [6], Richardson [7], Ruggles [8], and Tobin [9], all of whom argued that the issue was statistically inconclusive. Later, studies by, inter alia, Kuh [10], Bodkin [11], Modigliani [12], Lucas [1], Neftçi [13], Sargent [14], Otani [15], Chirinko [16], Geary and Kennan [17], Bils [18], Bernanke and Powell [19], and Keane et al. [20], find that the contemporaneous correlation between real wages and employment (or output) is either statistically insignificant or significantly positive. The most recent evidence shows that the cyclical behaviour of real wages has changed, from being countercyclical during the interwar period, to procyclical in the postwar era. For instance, studies by, inter alia, Solon et al. [21], Kydland [22], Hanes [23], den Haan [24], den Haan and Sumner [25], and Huang et al. [26], all show that the correlation between real wages and output have altered from being countercyclical during the interwar period to being procyclical during the postwar period, thereby supporting the contention espoused by real business cycle theorists over the postwar period.

Most of the empirical studies that analyse the behaviour of real wages focus on the US, with very little evidence produced for Australia. The objective of this paper is to bridge this gap, and analyse the behaviour of real wages for Australia, using quarterly observations for the period of 1984 : 1-2008 : 2. Much of the extant literature that model this behaviour use the short-run movement in real wages, as measured by its underlying rate of change. In this study, a more formal and rigorous approach is used to extract 
the unobserved cyclical components of the underlying variables, which is based on Harvey's $[27,28]$ structural time series model.

This paper is organised as follows. In the next section, a brief description of Harvey's [27, 28] structural time series model is provided, while in section 3 , the empirical results are reported. Section 4 provides some concluding remarks.

\section{Econometric Methodology}

In order for the cyclical behaviour of real wages to be analysed, time series data on the unobserved cyclical components is required. The approach taken in this study is to use the structural time series model developed by Harvey [27, 28]. The rationale for using this methodology is provided by, inter alia, Harvey et al. [29], and Harvey and Jaeger [30]. First, this approach allows investigators to deal explicitly with seasonal and irregular movements. This is important because if these two components are not dealt with properly, they may distort the cyclical component. Second, it provides the most useful framework within which to present stylized facts on time series, as it is explicitly based on the stochastic properties of the data. Finally, it provides useful information and serves as a basis for exposing the limitations of other techniques. The structural times series model may be written as:

$$
z_{t}=\mu_{t}+\varphi_{t}+\varepsilon_{t}
$$

where $z_{t}$ is the observed value of the series, $\mu_{t}$ is the trend component, $\varphi_{t}$ is the cyclical component, and $\varepsilon_{t}$ is the irregular component. The trend and cyclical components are assumed to be uncorrelated, while $\varepsilon_{t}$ is assumed to be white noise.

The trend component, which represents the long-term movement of a series, is assumed to be stochastic and linear. This component can be represented by the following equations:

$$
\begin{gathered}
\mu_{t}=\mu_{t-1}+\beta_{t-1}+\eta_{t}, \\
\beta_{t}=\beta_{t-1}+\zeta_{t},
\end{gathered}
$$

where $\eta_{t} \sim \operatorname{NID}\left(0, \sigma_{\eta}^{2}\right)$, and $\zeta_{t} \sim \operatorname{NID}\left(0, \sigma_{\zeta}^{2}\right)$. The trend component, $\mu_{t}$, is a random walk with a drift factor, $\beta_{t}$, which follows a first-order autoregressive process represented by (3).

The cyclical component, which is assumed to be a stationary linear process, may be represented by:

$$
\varphi_{t}=a \cos \theta t+b \sin \theta t
$$

where $t$ is time, and the amplitude of the cycle is given by $\left(a^{2}+b^{2}\right)^{1 / 2}$. To make the cycle stochastic, the parameters $a$ and $b$ are allowed to evolve over time, while continuity is preserved by writing down a recursion for constructing $\varphi_{t}$ before introducing the stochastic components. By introducing disturbances and a damping factor, we obtain:

$$
\begin{gathered}
\varphi_{t}=\rho\left(\mu_{t-1} \cos \theta+\mu_{t-1}^{*} \sin \theta\right)+\omega_{t}, \\
\varphi_{t}^{*}=\rho\left(-\mu_{t-1} \sin \theta+\mu_{t-1}^{*} \cos \theta\right)+\omega_{t}^{*},
\end{gathered}
$$

where $\varphi^{*}$ appears by construction such that $\omega_{t}$ and $\omega_{t}^{*}$ are uncorrelated white noise disturbances with variances $\sigma_{\omega}^{2}$ and $\sigma_{\omega^{*}}^{2}$, respectively. The parameters $0 \leq \theta \leq \pi$ and $0 \leq \rho \leq$ 1 are the frequency of the cycle and the damping factor on the amplitude, respectively. In order to make numerical optimisation easier, the constraint $\sigma_{\omega}^{2}=\sigma_{\omega^{*}}^{2}$ is imposed.

The extent to which the trend and cyclical components evolve over time depends on the values of $\sigma_{\eta}^{2}, \sigma_{\zeta}^{2}, \sigma_{\omega}^{2}, \theta$, and $\rho$, which are known as hyperparameters. These hyperparameters, along with the components, can be estimated by maximum likelihood using the Kalman filter to update the state vector. This procedure requires writing the model in state space form. Related smoothing algorithms can be used to obtain the estimates of the state vector at any point in time within the sample period.

The cyclical behaviour of any observed variable, $y$, is analysed by estimating the following model:

$$
\varphi_{t}^{y}=\beta_{0}+\beta_{1} \varphi_{t}^{x}+\beta_{2} \varphi_{t-1}^{y}+\varepsilon_{t}
$$

where $\varphi_{t}^{y}$ and $\varphi_{t}^{x}$ are the extracted cyclical components of the variables, $y$ and $x$, respectively. Since the unobserved cyclical components are stationary by construction, then conventional $t$-statistics can be used to derive inferences about the magnitudes of the estimated coefficients. A lagged dependent variable is included in (6) to reflect the autoregressive structure of the cyclical components. If $x$ is known to be a procyclical variable (such as employment), then a significantly positive coefficient on $\varphi_{t}^{x}$ in (6) indicates that $y$ is procyclical. On the other hand, if $x$ is known to be a countercyclical variable (such as unemployment), then a significantly negative coefficient on $\varphi_{t}^{x}$ in (6) would indicate that $y$ is countercyclical.

\section{Data and Empirical Results}

The cyclical behaviour of prices, $p$, and real wages, $w-p$, are analysed using three macroeconomic cyclical variables, these being the level of employment, the level of unemployment, and the unemployment rate. These cyclical variables are defined as follows: $e$ is the level of employment (measured in thousands of employees); $n$ is the level of unemployment (measured in thousands of people); $u$ is the unemployment rate (measured as a percentage of the total labour force). The nominal wage rate, $w$, is measured by average weekly earnings, while prices, $p$, are measured by the consumer price index. The real wage is constructed by deflating the nominal wage rate by the consumer price index. Quarterly observations on these variables covering the period 1984 : 12008 : 2, were obtained from the Australian Bureau of Statistics. All variables are expressed in natural logarithms, except for the unemployment rate, $u$.

As a preliminary exercise, Table 1 presents some descriptive statistics of the extracted cyclical components for prices, $\varphi^{p}$, real wages, $\varphi^{w-p}$, employment, $\varphi^{e}$, unemployment, $\varphi^{n}$, and the unemployment rate, $\varphi^{u}$. The results reported provide some basic idea about the size of the cyclical components extracted using Harvey's [27, 28] structural time series model. 
TABle 1: Descriptive statistics of the cyclical components.

\begin{tabular}{|c|c|c|c|c|c|}
\hline & $\phi^{p}$ & $\phi^{w-p}$ & $\phi^{e}$ & $\phi^{n}$ & $\phi^{u}$ \\
\hline Minimum & -0.0023 & -0.0094 & -0.0065 & -0.0041 & -0.0030 \\
\hline Maximum & 0.0029 & 0.0099 & 0.0060 & 0.0042 & 0.0036 \\
\hline Mean value & 0.0083 & -0.0047 & 0.0027 & 0.0019 & 0.0011 \\
\hline Std. Dev. & 0.0072 & 0.0047 & 0.0033 & 0.1885 & 0.0137 \\
\hline $\begin{array}{l}\text { Mean absolute } \\
\text { value }\end{array}$ & 0.6304 & 0.3958 & 0.2410 & 0.1604 & 0.1105 \\
\hline $\begin{array}{l}\text { Mean absolute } \\
\text { deviation from } \\
\text { trend }(\%)\end{array}$ & 0.9951 & 0.6855 & 0.9200 & 0.1267 & 0.5950 \\
\hline
\end{tabular}

TABLE 2: Correlation matrix of the cyclical components.

\begin{tabular}{lccccc}
\hline & $\phi^{p}$ & $\phi^{w-p}$ & $\phi^{e}$ & $\phi^{n}$ & $\phi^{u}$ \\
\hline$\phi^{p}$ & 1.0000 & & & & \\
& $(\infty)$ & & & & \\
$\phi^{w-p}$ & 0.2850 & 1.0000 & & & \\
& $(2.914)$ & $(\infty)$ & & & \\
$\phi^{e}$ & 0.1582 & 0.2070 & 1.0000 & & \\
& $(2.569)$ & $(2.073)$ & $(\infty)$ & & \\
$\phi^{n}$ & -0.0344 & -0.0835 & -0.2622 & 1.0000 & \\
& $(-3.374)$ & $(-8.209)$ & $(-2.662)$ & $(\infty)$ & \\
$\phi^{u}$ & -0.0244 & -0.0826 & -0.2782 & 0.9805 & 1.0000 \\
& $(-2.392)$ & $(-8.119)$ & $(-2.838)$ & $(9.890)$ & $(\infty)$ \\
\hline
\end{tabular}

Table 2 presents the correlation matrix of the extracted cyclical components, along with their respective $t$-statistics in parenthesis. The results show that all of the correlation coefficients between the cyclical components are highly significant. Furthermore, the results show that the cyclical component of prices is positively correlated with the cyclical component of employment, and negatively correlated with the cyclical components of unemployment and the unemployment rate. This suggests that prices are procyclical, a finding that is different to that obtained by Backus and Kehoe [31], Fisher et al. [32], and Cashin and Ouliaris [33], all of whom find that prices are countercyclical for Australia. A similar result is obtained with the cyclical components of real wages, indicating that it is positively correlated with the cyclical component of employment and negatively correlated with the cyclical components of both unemployment and the unemployment rate. This finding is in contrast to that obtained by Crosby and Otto [34], who find no relationship between the real wage and output for Australia.

In order to obtain more formal and rigorous evidence on the behaviour of real wages, (6) is estimated using the cyclical components of prices and real wages as dependent variables, and the cyclical components of employment, unemployment, and the unemployment rate as the explanatory variables. The results are reported in Table 3 (which uses the cyclical component of prices as the dependent variable) and Table 4 (which uses the cyclical components of real wages as the dependent variable).

These tables show the estimated coefficient, their respective $t$-statistics (in parenthesis), the adjusted coefficient
TABLe 3: OLS estimates of (2), when $y \equiv p$.

\begin{tabular}{lccc}
\hline & $x \equiv e$ & $x \equiv n$ & $x \equiv u$ \\
\hline$\beta_{0}$ & -0.608 & 0.226 & 0.150 \\
& $(-5.076)$ & $(9.384)$ & $(9.892)$ \\
$\beta_{1}$ & 0.106 & -0.020 & -0.030 \\
& $(5.794)$ & $(-6.759)$ & $(-6.732)$ \\
$\beta_{2}$ & 0.929 & 0.982 & 0.974 \\
& $(3.251)$ & $(4.043)$ & $(3.421)$ \\
\hline $\bar{R}^{2}$ & 0.9972 & 0.9851 & 0.9703 \\
$N(2)$ & 1.742 & 1.996 & 1.865 \\
$H S(2)$ & 2.897 & 0.586 & 0.546 \\
$F F(2)$ & 2.408 & 0.701 & 1.969 \\
$S C(2)$ & 1.705 & 1.741 & 2.145 \\
\hline
\end{tabular}

TABLe 4: OLS estimates of (2), when $y \equiv w-p$.

\begin{tabular}{lccc}
\hline & $x \equiv e$ & $x \equiv n$ & $x \equiv u$ \\
\hline$\beta_{0}$ & -0.146 & -0.113 & -0.022 \\
& $(-1.850)$ & $(-1.594)$ & $(0.424)$ \\
$\beta_{1}$ & 0.025 & -0.013 & -0.064 \\
& $(2.136)$ & $(2.916)$ & $(3.757)$ \\
$\beta_{2}$ & 0.949 & 1.021 & 1.011 \\
& $(3.156)$ & $(4.175)$ & $(3.475)$ \\
\hline $\bar{R}^{2}$ & 0.9607 & 0.9603 & 0.9590 \\
$N(2)$ & 1.965 & 0.423 & 0.063 \\
$H S(2)$ & 2.846 & 0.9205 & 2.610 \\
$F F(2)$ & 4.552 & 1.113 & 1.792 \\
$S C(2)$ & 3.012 & 1.920 & 1.328 \\
\hline
\end{tabular}

of determination, $\bar{R}^{2}$, as well as the diagnostic tests for normality, heteroscedasticity, functional form, and serial correlation, all of which have a $\chi^{2}$ distribution with two degrees of freedom. The equations are well determined, as shown by the goodness of fit measures, and easily pass all of the diagnostic tests in every case. The results shown in Table 3 indicate that the coefficient on the cyclical variable, $\beta_{1}$, is significantly positive when the cyclical variable is employment and significantly negative when the cyclical variable is either the level of unemployment or the unemployment rate. This result suggests that prices are procyclical. Similarly, Table 4 shows that $\beta_{1}$ is significantly positive when the cyclical variable is employment and significantly negative when the cyclical variable is either the level of unemployment or the unemployment rate, indicating that real wages are procyclical.

Given these findings, a procyclical real wage can only occur if nominal wages are flexible in both directions when prices change in a procyclical fashion. Changes in real wages are determined by changes in nominal wages and prices resulting from changes in the supply of and demand for labour. As economic conditions change over time, so too will the demand for and supply of labour. If the shift in the demand for labour is greater than the shift in supply, then real wages will be procyclical, even if prices are procyclical. 
An increase (decrease) in the real wage when prices are increasing (decreasing) requires the increase (decrease) in the nominal wage to be greater than the increase (decrease) in prices. Such a process, however, does not rule out obtaining any countercyclical behaviour, where the shift in the supply of labour is greater than the shift in the demand for labour, and this is why empirical testing is needed to resolve the issue.

\section{Concluding Remarks}

In this paper, the cyclical behaviour of prices and real wages has been examined for Australia, using quarterly observations for the period $1984: 1-2008: 2$. The results show that both prices and real wages are procyclical, suggesting that the change in the demand for labour is greater than the change in the supply of labour, thereby leading to a procyclical real wage even if prices are procyclical. This finding of a procyclical real wage supports the contention espoused by the real business cycle theorists.

\section{Acknowledgments}

This paper was written while the author was a visiting scholar at Case Western Reserve University, John Carroll University and the Federal Reserve Bank of Cleveland. The author would like to thank all three institutions for their gracious hospitality, along with G. N. Bornholt, A. J. de Silva, M. J. Dempsey, R. A. Heaney, O. F. Humpage, I. A. Moosa, C. Panousis, A. Posso, W. O. Simmons, J. B. Thomson, and S. M. Zuhair, for their comments and suggestions that have helped improve the quality of an earlier draft. The views expressed in the paper are those of the author and do not represent the views of the Federal Reserve Bank of Cleveland, or the Federal Reserve System. Any remaining errors are the responsibility of the author.

\section{References}

[1] R. E. Lucas, "Understanding business cycles," in Stabilisation of the Domestic and International Economy, K. Brunner and A. H. Meltzer, Eds., pp. 7-29, North Holland Press, Amsterdam, The Netherlands, 1977.

[2] K. G. Abraham and J. C. Haltiwanger, "Real wages and the business cycle," Journal of Economic Literature, vol. 33, no. 3, pp. 1215-1264, 1995.

[3] A. Brandolini, "In search of a stylised fact: do real wages exhibit a consistent pattern of cyclical variability?" Journal of Economic Surveys, vol. 9, no. 2, pp. 103-163, 1995.

[4] L. T. Dunlop, "The movement of real and money wage rates," The Economic Journal, vol. 48, no. 191, pp. 413-434, 1938.

[5] L. Tarshis, "Changes in real and money wages," The Economic Journal, vol. 49, no. 193, pp. 150-154, 1939.

[6] J. M. Keynes, "Relative movement of real wages and output," The Economic Journal, vol. 49, no. 193, pp. 34-51, 1939.

[7] J. H. Richardson, "Real wage movements," The Economic Journal, vol. 49, no. 195, pp. 425-441, 1939.

[8] R. F. Ruggles, "The relative movements of real and money wage rates," The Quarterly Journal of Economics, vol. 55, no. 1, pp. 130-149, 1940.
[9] J. Tobin, "Money wage rates and employment," in The New Economics: Keynes' Influence on Theory and Public Policy, S. E. Harris, Ed., pp. 572-590, Dobson Press, London, UK, 1948.

[10] E. Kuh, "Unemployment, production functions and effective demand," The Journal of Political Economy, vol. 74, no. 2, pp. 238-249, 1966.

[11] R. G. Bodkin, "Real wages and cyclical variations in employment: a re-examination of the evidence," Canadian Journal of Economics, vol. 2, no. 3, pp. 353-374, 1969.

[12] E. Modigliani, "The monetarist controversy or should we forsake stabilisation policies?” The American Economic Review, vol. 67, no. 1, pp. 1-19, 1977.

[13] S. N. Neftçi, "A time series analysis of the real wageemployment relationship," The Journal of Political Economy, vol. 86, no. 1, pp. 281-291, 1978.

[14] T. J. Sargent, "Estimation of dynamic labour demand schedules under rational expectations," The Journal of Political Economy, vol. 86, no. 6, pp. 1009-1044, 1978.

[15] I. Otani, "Real wages and business cycles revisited," The Review of Economics and Statistics, vol. 60, no. 2, pp. 301-304, 1966.

[16] R. S. Chirinko, "The real wage rate over the business cycle," The Review of Economics and Statistics, vol. 63, no. 3, pp. 459461, 1980.

[17] P. T. Geary and J. Kennan, "The employment-real wage relationship: an international study," The Journal of Political Economy, vol. 90, no. 4, pp. 854-871, 1982.

[18] M. Bils, "Real wages over the business cycle: evidence from panel data," The Journal of Political Economy, vol. 93, no. 4, pp. 666-689, 1985.

[19] B. S. Bernanke and J. L. Powell, "The cyclical behaviour of industrial labour markets: a comparison of the prewar and postwar eras," in The American Business Cycle: Continuity and Change, R. J. Gordon, Ed., pp. 583-621, University of Chicago Press, Chicago, Ill, USA, 1986.

[20] M. Keane, R. Moffitt, and D. Runkle, "Real wages over the business cycle: estimating the impact of heterogeneity with micro data," The Journal of Political Economy, vol. 96, no. 6, pp. 1232-1266, 1988.

[21] G. Solon, R. Barsky, and J. Parker, "Measuring the cyclicality of real wages: how important is composition bias?" The Quarterly Journal of Economics, vol. 109, no. 1, pp. 1-26, 1989.

[22] F. E. Kydland, "Business cycles and aggregate labour market fluctuations," in Frontiers of Business Cycle Research, T. F. Cooley, Ed., pp. 126-156, Princeton University Press, Princeton, NJ, USA, 1995.

[23] C. Hanes, "Changes in the cyclical behavior of real wage rates, 1870-1990," Journal of Economic History, vol. 56, no. 4, pp. 837-861, 1996.

[24] W. J. den Haan, "The comovement between output and prices," Journal of Monetary Economics, vol. 46, no. 1, pp. 330, 2000.

[25] W. J. den Haan and S. W. Sumner, "The comovement between real activity and prices in the G7," European Economic Review, vol. 48, no. 6, pp. 1333-1347, 2004.

[26] K. X. D. Huang, Z. Liu, and L. Phaneuf, "Why does the cyclical behavior of real wages change over time?" American Economic Review, vol. 94, no. 4, pp. 836-856, 2004.

[27] A. C. Harvey, "Trends and cycles in macroeconomic time series," Journal of Business and Economic Statistics, vol. 13, pp. 216-227, 1985.

[28] A. C. Harvey, Forecasting, Structural Time Series Models and the Kalman Filter, Cambridge University Press, Cambridge, UK, 1989. 
[29] A. C. Harvey, S. J. Koopman, and J. M. Penzer, "Messy time series: a unified approach," Advances in Econometrics, vol. 13, no. 1 , pp. 103-143, 1998.

[30] A. C. Harvey and A. Jaeger, "Detrending, stylized facts and the business cycle," Journal of Applied Econometrics, vol. 8, no. 1, pp. 231-247, 1993.

[31] D. K. Backus and P. J. Kehoe, "International evidence on the historical properties of business cycles," American Economic Review, vol. 82, no. 4, pp. 864-888, 1992.

[32] L. A. Fisher, G. Otto, and G. M. Voss, "Australian business cycle facts," Australian Economic Papers, vol. 35, no. 67, pp. 300-320, 1996.

[33] P. Cashin and S. Ouliaris, "Key features of Australian business cycles," Australian Economic Papers, vol. 43, no. 1, pp. 39-58, 2004.

[34] M. Crosby and G. Otto, "Real business cycle models: an introduction," Australian Economic Review, vol. 3, pp. 55-70, 1995. 


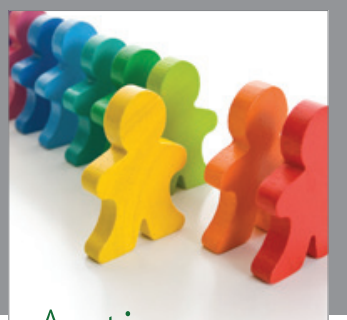

Autism

Research and Treatment
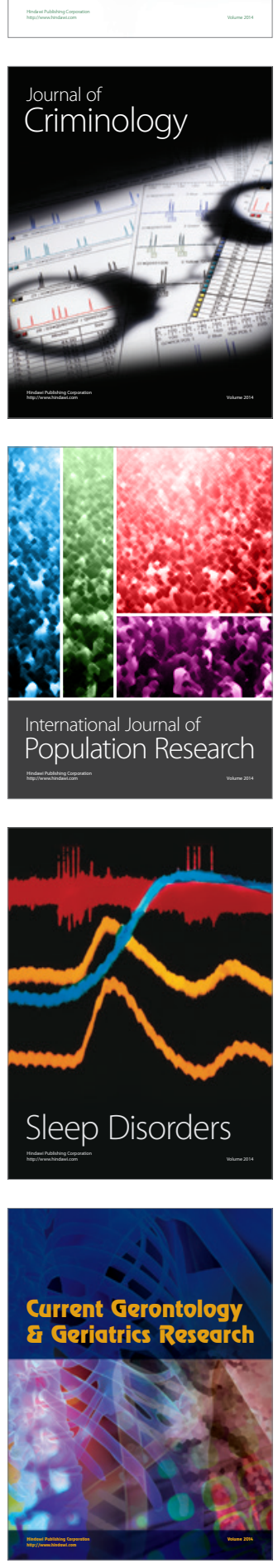
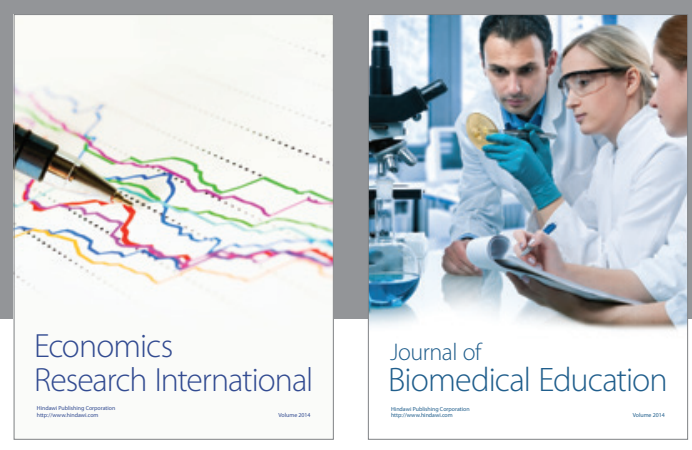

Journal of

Biomedical Education

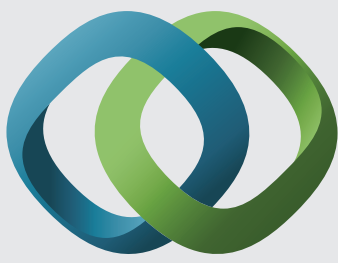

\section{Hindawi}

Submit your manuscripts at

http://www.hindawi.com
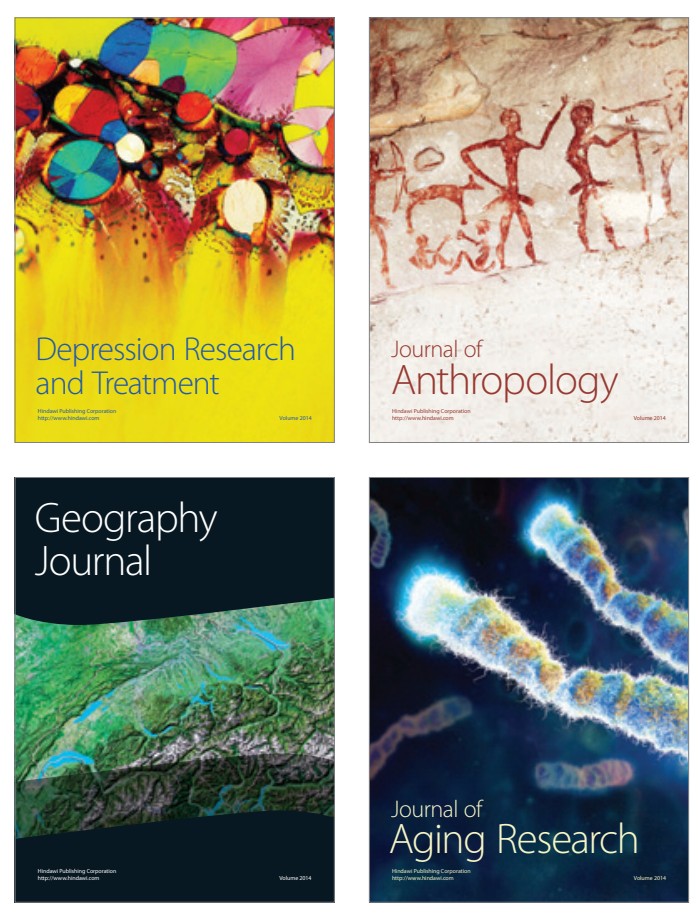

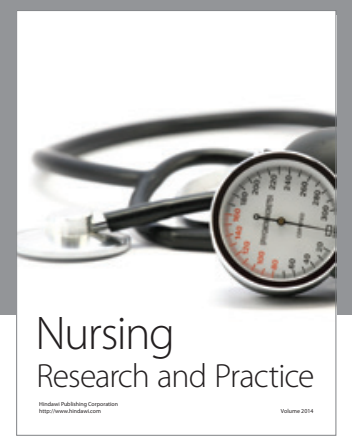

Nursing

Research and Practice

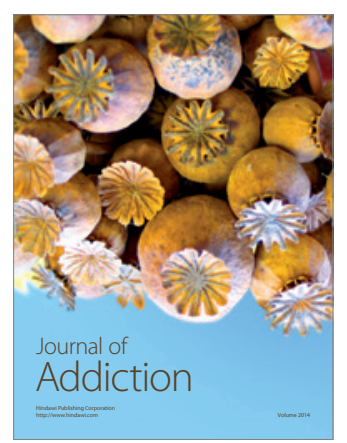

Child Development

Research

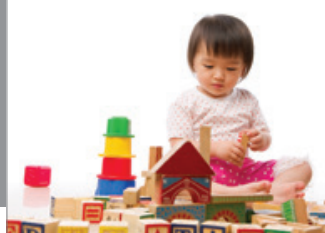

迥
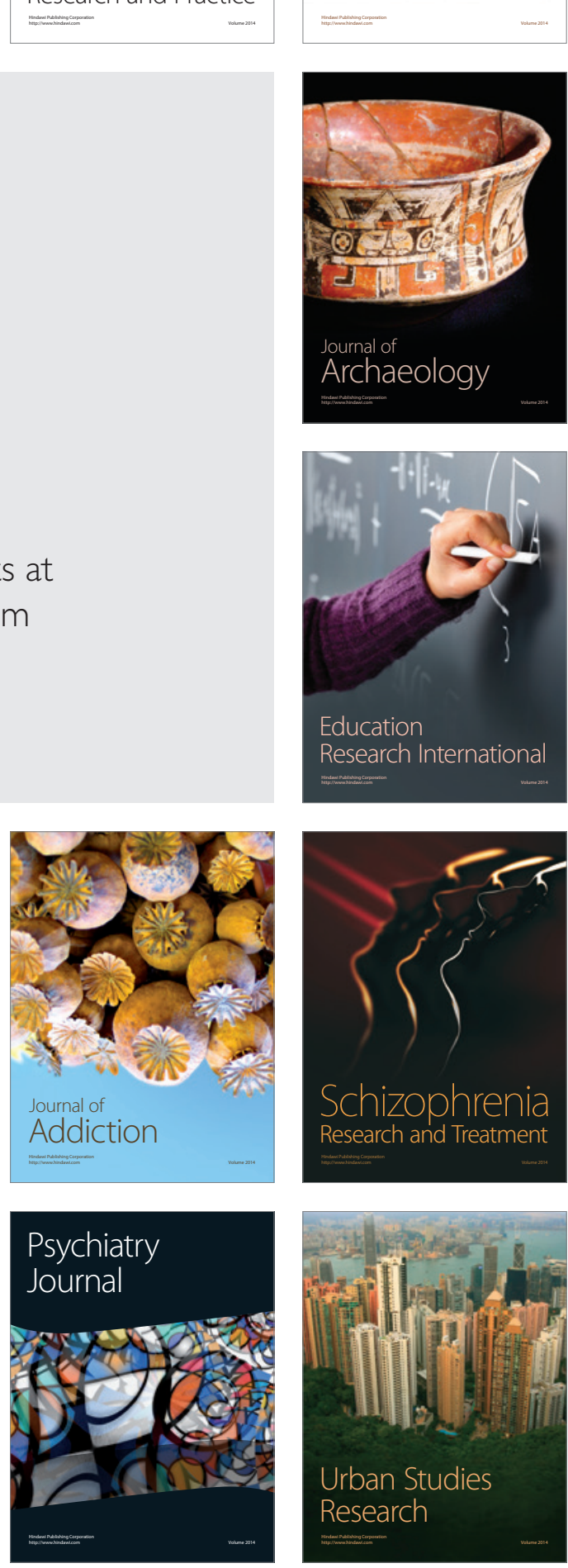